\title{
PRA-EKSISTENSI YESUS BERDASARKAN BUKTI-BUKTI INUIL YOHANES
}

\author{
Adi Putra \\ Sekolah Tinggi Teologi Pelita Dunia, Tangerang, Indonesia \\ Email: adiputra@gmail.com
}

\begin{abstract}
This paper discusses the pre-existence of Jesus based on some evidences in the Gospel of John. This subject discusses two things, namely: the divinity of Jesus and rejects views that do not approve of Jesus' pre-existence. In this paper uses a qualitative approach with the method of exegesis of several texts or passages in the Gospel of John, and based on some evidence from the Gospel of John, all of them confirm the pre-existence of Jesus, where He was even before the world was created.
\end{abstract}

Key words: pre-existence, evidence, divinity

\begin{abstract}
ABSTRAK
Artikel ini mendiskusikan pra-eksistensi Yesus didasarkan pada beberapa bukti dalam Injil Yohanes. Topik ini mendiskusikan dua hal, yaitu: keilahian Yesus dan pandangan-pandangan yang tidak mengakui pra-eksistensi Yesus. Artikel ini menggunakan pendekatan kualitatif dengan metode eksegesis dari beberapa teks atau bagian-bagian (pasal-pasal) dalam Injil Yohanes, dan didasakan pada beberapa bukti dari Injil Yohanes, semua menegaskan praeksistensi Yesus, di mana Ia bahkan ada sebelum dunia diciptakan.
\end{abstract}

Kata-kata kunci: pra-eksistensi, bukti, keilahian

\section{PENDAHULUAN}

Topik tentang pra-eksistensi Yesus merupakan topik yang krusial bagi setiap orang Kristen. Oleh karena topik ini langsung menyinggung inti iman Kristen, yakni keberadaan Yesus sebelum inkarnasi-Nya. Dengan kata lain, pra-eksistensi Yesus bisa juga dipahami sebagai pra-inkarnasi Yesus. Topik ini merupakan salah satu fondasi inti bagi iman Kristen. Itulah sebabnya ketika keliru dalam memahaminya, maka akan sangat berbahaya. Karena dapat mendistorsi seluruh ajaran yang lain, khususnya yang memiliki hubungan langsung atau masih berada dalam ranah kristologi. Oleh karena kristologi yang alkitabiah harusnya diawali dengan sebuah konsep yang benar tentang pra-eksistensi atau kekekalannya. Pokok pra- eksistensi Yesus $^{1}$ memiliki kaitan yang erat dengan doktrin trinitas dan doktrin keilahian

1 Seiring berkembangnya waktu, para teolog kembali mulai mempertanyakan akan kebenaran dari pengajaran ini. Banyak pendapat yang mulai dikemukakan oleh para theolog mengenai praeksistensi Kristus. Salah satunya seperti, ideal preexistence. Pengajaran ini berkata bahwa Kristus memiliki eksistensi di dalam pikiran Tuhan sebelum inkarnasi, namun tidak benar-benar ada sebagai sebuah entitas. Pandangan ini mengklaim bahwa tidak ada satu waktu pun ketika Kristus tidak berada dalam rencana Bapa. Kristus sama tuanya dengan rencana keselamatan Tuhan: yaitu rencana-Nya yang menyatakan kemenangan-Nya atas kematian dan direncanakan sejak dalam kekekalan sebagai bagian dari kehendak Tuhan yang agung. Sepertinya hal ini kelihatan benar, tetapi jika demikian apa bedanya dengan engkau dan saya. Kita juga sudah berada dalam rencana Bapa sejak kekekalan. Banyak lagi interpretasi mengenai praeksistensi Kristus yang berkembang mulai abad-abad terakhir. Hal ini sangat disebabkan oleh worldview kita. (Sumber: http://www.buletinpillar.org/artikel/paulswriting-on-preexistence-of-christ//03/03/2019//) 
Yesus (baca: Kristologi). Meskipun secara spesifik, topik ini memuat dua fakta yang krusial yang perlu klarifikasi tuntas dalam kaitannya dengan pra-eksistensi Yesus, yakni: (1) fakta yang berhubungan dengan prainkarnasi berdasarkan bukti-bukti Alkitab (dalam tulisan ini spesifik kepada PB); dan (2) fakta yang berhubungan dengan kekekalanNya.

Dengan demikian, secara sederhana topik pra-eksistensi Yesus bermaksud menjawab pertanyaan-pertanyaan skeptis tentang keilahian (kekekalan) Yesus. Apakah Yesus benar-benar adalah Anak Allah? Apakah Dia benar pribadi kedua dalam Allah Tritunggal? Ataukah Yesus hanyalah manusia yang memiliki moral dan keteladanan yang patut dicontoh? Dengan kata lain, Yesus bukan Allah? Tulisan ini akan menjawab dan memberikan klarifikasi berdasarkan buktibukti yang diperoleh dari Injil Yohanes.

\section{APA PRA-EKSISTENSI YESUS ITU?}

Donald Macleod mengatakan, "The preexistence of Christ is clearly affirmed in the Nicene Creed: he was 'begotten of the Father before all worlds'. The doctrine clearly implies that originally Christ was not like us; that he came to be like us only by voluntarily sharing our life; that, as the particular individual he was, he existed before creation; and that his existence as a man was continuous with his earlier existence as a heavenly being". 2 Jadi bagi Macleod, praeksistensi Kristus dengan jelas telah ditegaskan dalam Pengakuan Iman Nicea: ia ' telah diperanakkan oleh Bapa sebelum seluruh dunia (diciptakan)'. Ajaran ini dengan jelas menyatakan bahwa pada mulanya Kristus tidak seperti kita; bahwa Dia kemudian menjadi seperti kita hanya dengan secara sukarela membagikan hidup kita; bahwa, sebagai individu dia telah ada, dia ada sebelum penciptaan; dan bahwa keberadaannya sebagai manusia terus-menerus dengan

2 Donald Macleod, The Person of Christ: Contours of Christian Theology, (USA: InterVarsity Press, 1998), 45.
keberadaan-Nya terdahulu sebagai makhluk surgawi.

Beberapa teolog lain juga memberikan pemahaman atau pengertian tentang praeksistensi Yesus. Secara umum, mereka berpendapat bahwa Yesus telah ada sebelum dilahirkan, sebelum penciptaan, dan sebelum adanya waktu (kekal). Seperti yang dikatakan oleh Charles C. Ryrie, "Pra-eksistensi Kristus berarti Kristus telah ada sebelum dilahirkan". ${ }^{3}$ Sedangkan J. Knox Chamblin menjelaskan, "Sebelum menjadi manusia, Kristus berada 'dalam rupa Allah' (Flp. 2:6a), yaitu 'serupa dengan Allah' (Flp.2:6b) - kedua istilah ini menyatakan perbedaan Kristus dari Allah (Theos) sekaligus menegaskan keilahian-Nya. Ekspresi ayat 6a melukiskan pra-eksistensi Kristus dalam jubah kemuliaan dan kemegahan ilahi. Ia dalam rupa Allah, berbagi kemuliaan Allah". ${ }^{4}$ Ditambahkan oleh Ryrie, "Kekekalan tak hanya berarti bahwa Kristus sudah ada sebelum kelahiran-Nya atau bahkan sebelum penciptaan, dan adanya waktu, tetapi bahwa Ia selalu ada, selama-lamanya". 5

\section{AJARAN YANG MENOLAK PRA- EKSISTENSI YESUS}

Ebionisme. Paham ini merupakan bidat yang berkembang pada abad kedua dan ketiga. Mereka juga dikenal dengan paham adopsianisme yang lahir pada abad kedua. Tokohnya seperti Cerinthus dan Carpocrates berpendapat, Yesus hanyalah anak Yusuf, itulah sebabnya dia tidak lebih dari manusia yang lain. Tidak hanya menolak konsep praeksistensi Yesus, tetapi juga keilahian Yesus. Paham ini juga menekankan bahwa Yesus hanyalah manusia biasa, sehingga tidak mungkin memiliki pra-eksistensi. Argumen ini sejalan dengan apa yang dikatakan oleh Millard J. Erickson, "Yesus adalah manusia biasa yang dikaruniai sifat-sifat kebenaran dan

3 Charles C. Ryrie, Teologi Dasar Jilid 2, (Yogyakarta: Penerbit ANDI, 1991), 321.

4 J. Knox Chamblin, Paulus dan Diri: Ajaran Rasuli bagi Keutuhan Pribadi, (Surabaya: Momentum, 2011), 62.

${ }^{5}$ Ryrie, Teologi Dasar Jilid 2, 322. 
hikmat yang luar biasa tetapi tidak adikodrati. Memang Dia ditakdirkan menjadi Mesias sekalipun hanya dalam pengertian alamiah dan manusiawi". 6

Arianisme. Arianisme adalah bidat yang berkembang pada abad keempat dipelopori Arius dari Alexandria. Arius menolak konsep Alexandria tentang konsep "homoousios" yang mengakui bahwa Bapa dan Anak sehakekat atau setara. Sebaliknya ia berpendapat bahwa hanya Bapa sebagai Allah yang sejati, sedangkan Anak, yaitu Yesus atau Logos dilahirkan dan diciptakan oleh Bapa. Menurut Arius, Kristus adalah manusia yang dapat berdosa dan yang tidak sempurna.

Pandangan Arianisme yang secara langsung menolak pra-eksistensi Yesus adalah ketika mereka menganggap "hanya Allah (maksud Arius hanya Allah Bapa saja) yang tidak pernah diciptakan serta kekal sifatnya. Semua yang lain adalah makhluk ciptaanNya". 7

Socinianisme. Paham ini mempengaruhi Unitarianisme Inggris dan Deisme Inggris. Kebanyakan penganut unitarianisme bukan penganut Deisme, tetapi semua penganut Deisme mempunyai konsep unitarian tentang Allah. Garis bidatnya adalah Arianisme ke Socinianisme ke Unitarianisme ke Deisme. ${ }^{8}$

Socinianisme mengajarkan hanya ada satu zat ilahi yang terdiri hanya satu pribadi. Walau mengikuti Arius, tetapi Socinus melampaui Arianisme dalam penyangkalannya tentang pra-eksistensi Anak (baca: Yesus) dan menganggap Anak hanya seorang manusia. ${ }^{9}$

Saksi Yehova. "Saksi Yehuwa percaya Yesus Kristus sebagai "suatu allah" yaitu ciptaan Allah, tidak satu hakekat dengan Allah Bapa alias bukan Allah sejati. Dengan demikian setiap Saksi Yehuwa tidak

\footnotetext{
${ }^{6}$ Millard J. Erickson, Teologi Kristen. Volume Dua (Malang: Gandum Mas, 2015), 333.

${ }^{7}$ Erickson, Teologi Kristen, 335.

8 Charles C. Ryrie, Teologi Dasar Jilid 1, (Yogyakarta: Penerbit ANDI, 1991), 78.

${ }_{9}$ https://teologiareformed.blog-spot.com/2018/09/pra-eksistensi-dan-kekekalan-kristus.html//03/03/2019//
}

memberikan penyembahan kepada Yesus sebagai Allah. Hanya Allah Bapa saja adalah Allah yang benar dan sejati. Konsep ini dikenal dengan istilah Unitarian."10

\section{BUKTI-BUKTI DARI INJIL YOHANES}

\section{Yohanes 1:1}

"Pada mulanya adalah Firman; Firman itu bersama-sama dengan Allah dan Firman itu adalah Allah". Ayat ini dapat dibagi ke dalam tiga bagian; di mana ketiga-tiganya menekankan tentang pra-eksistensi Yesus. Seperti: Yesus sudah ada sejak semula, Yesus bersama-sama dengan Allah Bapa, dan Yesus sendiri juga adalah Allah (pribadi kedua dalam doktrin Allah Tritunggal).

Ada tiga ungkapan atau frasa dalam ayat ini yang merujuk kepada pra-eksistensi Yesus. Ketiga ungkapan itu adalah 'Ev $\dot{\alpha} \rho \chi \tilde{n}$ (pada

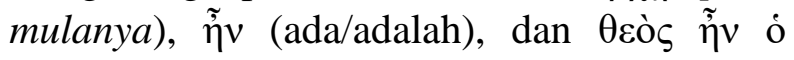
$\lambda$ ó́os (Firman itu adalah Allah). 'Ev $\alpha \rho \chi \tilde{n}$ atau seringkali diterjemahkan dengan in the beginning atau pada mulanya pertama kali muncul dalam Kejadian 1:1 dalam konteks penciptaan langit dan bumi. Menurut Carson, "Both in Genesis and here, the context shows that the beginning is absolute: the beginning all things, the beginning of the universe. The Greek word behind 'beginning', arche, often bears the meaning 'origin' ( $c f$. BAGD), and there may be echoes of that here, for the Word who already was 'in the beginning' is soon shown to be God's agent of creation (vv.3-4), what we might call the 'originator' of all things". 11 .

Maksudnya, bagi Carson baik di Kejadian dan di Injil Yohanes, konteksnya menunjukkan bahwa beginning adalah mutlak: permulaan segala sesuatu, permulaan alam semesta. Kata Yunani dibalik 'beginning', arche, sering mengandung

10 https://saksi-saksi-yehuwa.blogspot.com/2014/05/siapakah-yesus-menurut-ajaran-saksiyehuwa.html//02/03/2019//Pukul. 23.14 WIB.

${ }^{11}$ Carson, The Gospel According to John. The Pillar NTC (Leicester/Grand Rapids: Eerdmans, 1991), 114. 
makna 'asal/sumber/asal-usul' (band. BAGD), dan mungkin saja ada gema tersebut di Yohanes 1:1, yang menunjuk kepada Firman yang telah ada sejak semula akan segera terbukti menjadi agen penciptaan Allah (ay. 34), yang kita boleh sebut 'pencetus' dari segala sesuatu.

Kemudian istilah $\tilde{\eta} v$ merupakan bentuk

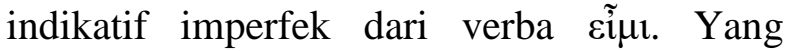
menarik karena dalam tiga frasa pada ayat 1 , verba $\varepsilon \tilde{\mu} \mu \mathrm{r}$ selalu muncul dalam bentuk yang sama. Carson mengatakan,

Although meaning of $\bar{e} n$ (was) and egeneto (rendered 'were made' in v. 3 , 'came' in v. 6 and 'became' in v. 14) often overlap, John repeatedly uses the two verbs side by side to establish something of a contrast. For example, in 8:58 Jesus insists, "[Before] Abraham was born [a form of the second verb], I am [a form of the first verb]. In other words, when John uses the two verbs in the same context, $\bar{e} n$ frequently signals existence, whereas egeneto signals 'coming into being' or 'coming into use'. In the beginning, the Word was already in existence. ${ }^{12}$

Menurut Carson, meskipun arti $\bar{e} n$ dan egeneto seringkali tumpang tindih, akan tetapi Yohanes seringkali menggunakan kedua verba ini secara berdampingan untuk membangun suatu hal yang kontras, misalnya dalam 8:58. Dengan kata lain, ketika Yohanes meng-gunakan kedua kata kerja ini dalam konteks yang sama, èn sering mengisyaratkan tentang 'keberadaan', sedangkan egeneto meng-isyaratkan 'datang menjadi' atau 'mulai digunakan'. Pada mulanya, Firman itu sudah ada.

Dengan demikian, kata kerja $\tilde{\eta} v$ juga hendak menegaskan eksistensi Firman (Yesus) yang telah ada sejak kekekalan. Jauh sebelum Allah menciptakan langit dan bumi. Sekaligus meruntuhkan asumsi dari Arius yang menegaskan, ada pada suatu waktu di

\footnotetext{
${ }^{12}$ Carson, The Gospel According to John, 114.
}

mana Firman itu tidak ada. Oleh karena berdasarkan kata kerja ini Firman itu tidak berawal - Dia tidak diciptakan. Karena sejak semula Firman itu sudah ada.

Terakhir frasa $\theta \varepsilon o ̀ \varsigma \tilde{\eta} v$ ó $\lambda o ́ \gamma o \varsigma$ (Firman itu adalah Allah). Frasa ini menimbulkan banyak perdebatan dalam kalangan ahli biblika. Perdebatan itu terutama menyangkut nomina $\theta \varepsilon$ c̀s. Seperti dijelaskan oleh Daniel Wallace, ada kelompok yang mengartikan $\theta \varepsilon$ ò $\varsigma$ sebagai 'a god', oleh karena predikat nominatif di sini adalah indefinite (tak tentu). Ungkapan tersebut termaktub dalam pendapat Wallace, "The indefinite notion is the most poorly attested for anarthrous pre-verbal predicate nominatives. Thus, grammatically such a meaning is improbable. Also, the context suggests that such is not likely, for the Word already existed in the beginning. Thus, contextually and grammatically, it is highly improbable that the Logos could be 'a god' according to John". 13

Menurut Wallace, gagasan indefinite adalah pembuktian yang paling buruk untuk anarthrous nominatif predikat sebelum verba. Dengan demikian makna yang seperti itu adalah hal yang mustahil. Juga berdasarkan konteksnya hal itu tidak mungkin, karena Firman telah muncul di awal. Maka, berdasarkan konteks dan gramatikalnya, Firman bisa menjadi 'sebuah allah' sangat tidak mungkin.

Berdasarkan pendapat Wallace, maka dapat dikatakan gagasan ini adalah sesuatu yang mustahil. Oleh karena hal ini bertolak belakang dengan prinsip kristologi yang diusung oleh keempat Injil, di mana Yesus Kristus diidentifikasikan sebagai Allah. Oleh

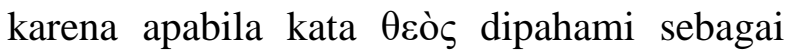
indefinite dengan memberikan arti 'a god', maka implikasi teologinya akan menjadi sama dengan bentuk politeisme.

Ada juga kelompok yang menyebutnya sebagai predikat nominatif definite (tertentu). Wallace memberikan kelemahan dari

13 Daniel B. Wallace, Greek Grammar Beyond and Basics: An Exegetical Syntax of The New Testament, (Grand Rapids: Zondervan, 1996), hlm.267. 
pandangan ini, "The problem of this argument is that the $\theta \varepsilon$ ò $\varsigma 1: 1^{\mathrm{b}}$ is the Father. Thus to say that the $\theta \varepsilon$ ò $1: 1^{\mathrm{c}}$ is the same person is to say that the Word was the Father. This, as the older grammarians and exegetes pointed out, is embryonic Sabellianism or modalism". ${ }^{14}$

Dengan demikian, bahaya dari pandangan yang kedua ini adalah adanya kemungkinan untuk terjerumus ke dalam konsep Sabelianime dan Modalisme, di mana secara garis besar kedua-duanya tidak membedakan antara Firman (Yesus Kristus) dan dengan Allah (Bapa). Apabila memahami

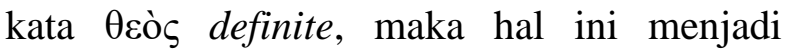
embrio bagi kedua pandangan yang keliru di atas.

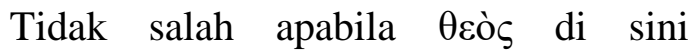
dikategorikan ke dalam predikat nominatif yang kualitatif. Oleh karena prinsip ini (kualitatif) benar secara gramatikal dan teologi. Wallace menjelaskan demikian, "There is a balance between the Word's diety, which was already present in the beginning (Ev à $\rho \chi \tilde{\eta} \ldots . . . \theta \varepsilon o ̀ \varsigma \tilde{\eta} v ~[1: 1]$, and humanity,

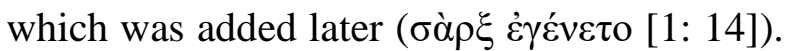
The grammatical structure of these two statements mirrors each other; both emphasize the nature of the Word, rather than his identity. But $\theta \varepsilon$ ò $\varsigma$ was his nature from eternity (hence, eimi is used), while $\sigma \grave{\alpha} \rho \xi$ was added at the incarnation (hence, ginomai is used)". ${ }^{15}$

Dengan demikian, berdasarkan pandangan Wallace di atas, terdapat keseimbangan antara keilahian Firman, yang hadir sejak semula ('Ev à $\rho \chi \tilde{n} \ldots . . . \theta \varepsilon$ ò $\varsigma \tilde{\eta} v$ [1:1], dan kemanusiaan yang ditambahkan

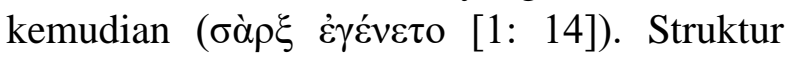
gramatikal dari kedua pernyataan di atas saling mencerminkan satu dengan yang lain, keduanya menekankan sifat Firman, bukan identitasnya. Tapi $\theta \varepsilon$ ò $̧$ adalah sifat-Nya dari kekekalan (maka, eimi digunakan), sementara $\sigma \grave{\rho} \rho \xi$ ditambahkan pada inkarnasi (maka, ginomai digunakan).

\footnotetext{
267-68.

${ }^{14}$ Wallace, Greek Grammar Beyond and Basics,

${ }^{15}$ Wallace, Greek Grammar Beyond and Basics,
}

Pendapat Wallace di atas dibenarkan oleh J. Ramsey Michaels. Michaels mengatakan,

At the same time, the absence of the article alerts the reader that 'the Word' and 'God', despite their close and intimate relationship, are not interchangeable. While the Word is God, God is more than just the Word. Even though it stands first in its clause, 'God' is the predicate noun and not the subject in the clause, that is, 'the Word was God', not 'God was the Word' (compare 4:24, God is Spirit, not 'Spirit is God'). ${ }^{16}$

Pada saat yang sama, ketika kata sandang tidak ada maka itu memperingatkan pembaca bahwa 'Firman' dan 'Tuhan', meskipun hubungan mereka yang akrab dan intim, tidak dapat saling dipertukarkan. Sementara Firman itu adalah Allah, dan Allah lebih dari hanya Firman. Meskipun ia berdiri pertama dalam klausulnya, 'Allah' adalah kata benda utama dan bukan subjek dalam klausa itu, yaitu, 'Firman itu adalah Allah', bukan 'Allah adalah Firman' (bandingkan 4:24, Allah adalah Roh), bukan 'Roh adalah Tuhan'. Pandangan Michaels ini memperkuat argumentasi Wallace di atas.

Dengan demikian, melalui frasa yang ketiga ini dapat dikatakan bahwa Firman (Yesus) memiliki sifat ilahi - Allah yang dalam Pribadi-Nya berbeda dari Bapa. Keilahian Yesus sudah dimiliki-Nya sejak kekekalan. Maka sekali lagi bagian ini mempertegas doktrin pra-eksistensi, sekaligus keilahian Yesus dan menolak dan meruntuhkan tuduhan saksi Yehova yang menganggap Yesus hanyalah ciptaan.

\section{Yohanes $1: 14 ; 1: 18 ; 3: 16$; dan 3:18}

Pada empat ayat di atas muncul istilah monogeness $^{17}$. Menurut Tenney, istilah

16 J. Ramsey Michaels, The Gospel of John (NICNT), (Grand Rapids: Zondervan, 2010), 48.

17 TDNT menegaskan penggunaan istilah monogenès dalam konteks PB sebagai berikut: “(1) In 
monogenēs ${ }^{18}$ dalam Injil Yohanes (ay.14 dibentuk dari genos, sehingga akan lebih tepat diartikan sebagai one of a kind, only, atau unique, sebaliknya tidak tepat untuk diterjemahkan dengan only begotten. Karena, konsep pemikiran di balik monogenēs adalah Kristus sebagai Anak Tunggal Allah, Ia tidak setara dengan yang lain dan dalam diri-Nya Allah sebagai Bapa dapat dengan seutuhnya dinyatakan. Singkat kata, penyataan Allah melalui Kristus adalah satu-satunya dan tidak berulang.

Kemudian ditambahkan oleh Leon Morris, kita jangan terlalu sering membaca 'yang diperanakkan'. Karena, bagi yang berbahasa Inggris, kata ini terdengar seperti hubungan metafisik. Padahal, istilah Yunaninya berarti 'hanya', 'unik'. Sebagai contoh, kata ini yang digunakan dalam cerita

the NT the term occurs only in Luke, John, and Hebrews. Isaac is monogenēs in Heb. 11:7, and the son of the widow at Nain (Lk. 7:12), the daughter of Jairus $(8: 42)$, and the demoniac boy $(8: 42)$ are all only children; (2) Only John uses the term for Jesus. John calls Christians the tekna of God rather than his huioi (cf. 1:12;11:52; 1 Jn. 3:1 ). Jesus is the only huios; his unique relation to God is thus given emphasis. God is the pater idios of Jesus; no others stand in the same relationship (Jn. 5:18). It is thus that Jesus is monogenes (Jn. 1:14; 3:16; 1 Jn. 4:9). Because he is the only-begotten Son, his sending into the world is a supreme proof of God's love (Jn. 3:16). But it also means that decision for life or death takes place in relation to him (3:18). As the only-begotten Son he shares all things with the Father. His glory is not merely like that of an only child; it is that of the onlybegotten Son (1:14). He is not just unique; he is the Son, for combined with huios the term describes his origin. The risen Lord is also the preexistent Lord, who is with God, is loved by him, and shares his glory from all eternity $(17: 5,24)$. Whether or not this implies actual begetting by God is debated by some, but $1 \mathrm{Jn}$. 5:18 definitely teaches this, for sonship is here presented in terms of begetting. John does not lift the veil of mystery that lies over the eternal begetting, for he aims to awaken faith rather than give systematic knowledge."

18 BDAG menjelaskan istilah monogenēs mengacu kepada dua hal: (1) pert. to being the only one of its kind within a specific relationship, one and only, only; (1) pert. to being the only one of its kind or class, unique (in kind) of something. (1)untuk menjadi satusatunya dari jenisnya dalam hubungan tertentu, satusatunya, hanya; (1) untuk menjadi satu-satunya dari jenis atau kelasnya, unik (sejenis) dari sesuatu.). janda Nain: ini 'hanya' anak (Luk. 7:12 lih. juga Luk. 9: 38). Kata yang sama juga digunakan dalam cerita Yairus (Luk. 8:42) 'hanya' Putri. Mungkin bahkan lebih instruktif adalah penggunaan istilah yang mengacu pada Ishak (Ibr. 11:17) sebagai Ishak yang bukan anak tunggal Abraham. Tapi, dirinya 'unik'. Ishak adalah satu-satunya anak yang diberikan kepada Abraham dengan janji Allah. Dalam penggunaannya di sini, kata monogenēs tidak selalu menunjukkan hubungan metafisik, tetapi mau menunjukkan bahwa Yesus adalah Anak Allah dengan cara yang unik. Dan, ciri unik dari hubungan antara Bapa dan Anak adalah salah satu tema besar Injil Yohanes. ${ }^{19}$

Hal yang serupa pun dikemukakan oleh Andreas J. Kostenberger: "The introduction to John's gospel refers to Jesus as the monogenēs or 'one and only Son' from the Father (John 1:14) and stresses his unique relationship with him (1:18)" (Pengantar Injil Yohanes merujuk pada Yesus sebagai monogen atau 'Anak satu-satunya' dari Bapa (Yohanes 1:14) dan menekankan hubungannya yang unik dengannya (1:18)). Bahkan disimpulkan oleh Kostenberger, "Monogenēs, therefore, means in all likelihood, not 'only begotten' but 'one-of-a-kind' son" (Karenanya, monogenes berarti dalam segala kemungkinan, bukan 'anak yang diperanakkan' tetapi 'anak yang unik'). ${ }^{20}$

Carson menambahkan, "The glory displayed in the incarnate Word is the kind of glory a father grants to his one and only, bestloved Son - and this 'father' is God himself'( Kemuliaan yang ditampilkan dalam Firman yang berinkarnasi adalah jenis kemuliaan yang diberikan Bapa kepada Putranya satu-

19 Leon Morris, The International Commentary On The New Testament: The Gospel According To John. (Grand Rapids, Michigan: Wm. B. Eerdmans Publishing Co, 1971), 105.

${ }^{20}$ Andreas J. Kostenberger, A Theology John's Gospel and Letters: The Word, the Christ, the Son of God, Grand Rapids, Michigan: Wm. B. Eerdmans Publishing Co., 2009), 381. 
satunya, yang paling dicintai - dan 'Bapa' ini adalah Allah sendiri). ${ }^{21}$

J. Ramsey Michaels memberikan komentar yang identik dengan Kostenberger dan Carson tentang makna istilah monogenēs menurut Injil Yohanes dengan mengatakan, "It is widely recognized that the synoptic term 'beloved' (agapetos; compare Mt. 12:18; Mk. 12:6; Lk. 20:13) and the Johannine 'One and Only' (monogenēs, compare 1:18; 3:16,18; 1Jn. 4:9) and almost equivalent terms, both accenting the uniqueness of Jesus' relationship to the Father" (Secara luas diakui bahwa istilah sinoptik 'terkasih' (agapetos; bandingkan Matius 12:18; Markus 12: 6; Luk 20:13) dan Yohanes 'Satu-Satunya' (monogenes, bandingkan 1:18; 3 : 16,18; 1Yoh. 4: 9) dan istilah yang hampir setara, keduanya menekankan keunikan hubungan Yesus dengan Bapa.). ${ }^{22}$

Dengan demikian, makna monogenēs dalam Injil Yohanes hendak menekankan sebuah relasi yang unik antara Yesus (Anak) dengan Allah, bukan hendak menekankan sebuah hubungan metafisik. bahkan seperti yang dikemukakan Michaels bahwa ungkapan monogeness sepadan dengan ungkapan agapetos dalam Injil Sinoptik. Penggunaan istilah monogeness dalam Injil Yohanes hendak menegaskan relasi yang unik antara Yesus Kristus dengan Allah Bapa. Di mana relasi itu tidak harus berada dalam konteks hubungan secara metafisik atau diperanakkan, karena bukan makna itu yang hendak ditekankan oleh istilah monogenēs. Kata bentukan monogenēs dipakai untuk menggambarkan keunikan relasi antara Allah dan Yesus Kristus; bahwa Yesus adalah sama dengan Allah. Jadi, sekali lagi dari istilah ini juga hendak menekankan tentang praeksistensi dan keilahian Yesus.

\section{Yohanes 8:58}

Kata Yesus kepada mereka: "Aku berkata kepadamu, sesungguhnya sebelum Abraham jadi ( $\gamma \varepsilon v \varepsilon ́ \sigma \theta \alpha \mathrm{l})$, Aku telah ada"

\footnotetext{
${ }^{21}$ Carson, The Gospel According to John, 128.

${ }^{22}$ Michaels, The Gospel of John, 80.
}

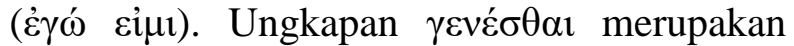

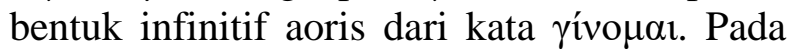
penjelasan sebelumnya telah dikatakan oleh Carson bahwa ungkapan rívo $\mu \alpha$ tidak menegaskan eksistensi yang kekal melainkan "menjadi" atau "mulai digunakan". Dalam pengertian bahwa Abraham tidak memiliki pra-eksistensi karena dia juga diciptakan atau memiliki awal. Ungkapan ini seolah-olah dipertentangkan dengan ungkapan yang mengikutinya, yakni: $\dot{\varepsilon} \gamma \omega \dot{~ \varepsilon i ̉ \mu t . ~ C a r s o n ~}$ mengatakan,

Abraham looked forward to the messianic age, the age that was, in John's understanding, inaugurated by the incarnation of the Word who already was in the beginning' (1:1), like God, eternal. In conformity with John's Prologue, Jesus takes to himself one of the most sacred of divine expressions of self-reference, and make assumption of that expression the proof of his superiority over Abraham." 23

Jadi, menurut Carson, dalam konteks ini Abraham memandang ke depan ke zaman mesianik, zaman yang menurut pemahaman Yohanes, diteguhkan oleh inkarnasi Firman (Yesus) yang sudah ada 'pada mulanya' (1:1), seperti Allah (Bapa), Yesus juga kekal. Sesuai dengan Prolog Yohanes, Yesus mengambil bagi dirinya sendiri salah satu ekspresi ilahi yang paling sakral dari rujukan diri, dan menjadikan asumsi ungkapan itu sebagai bukti keunggulan Yesus jauh melampaui Abraham.

Dalam Injil Yohanes, Yesus menggunakan bentuk Ego Eimi yang muncul sebanyak 7 kali. Yesus mengatakan bahwa diri-Nya adalah "Roti" (Yoh 6:35 "Ego eimi ho Artos"), "Terang Dunia" (Yoh 8:12, "Ego eimi to Phos tou kosmou"), "Pintu" (Yoh 10:7, "Ego eimi he Thura ton Probaton"),"Gembala" (Yoh 10:11, "Ego eimi ho Poimen ho Kalos") "Kebangkitan dan Hidup" (Yoh 11:25 "Ego eimi he Anastasis kai he Zoen"), "Jalan, Kebenaran, Hidup" (Yoh 14:6, "Ego eimi ho Hodos kai he Aletheia kai

\footnotetext{
${ }^{23}$ Carson, The Gospel According to John, 358.
} 
he Zoen"), "Anggur" (Yoh 15:1, "Ego eimi he Ampelos he alethine").

Donald Guthrie juga memberikan

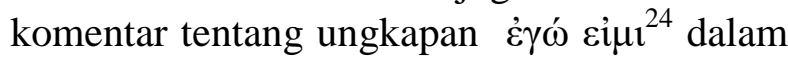
Injil Yohanes dengan berkata, "Melalui perkataan 'Aku adalah', Yesus membuat halhal yang masih abstrak dalam pendahuluan Injil menjadi nyata dalam pribadi. Hal ini menyangkut hidup, kebenaran dan juga terang. Yohanes memperlihatkan bahwa Yesus menyatakan diri sebagai perwujudan dari semua cita-cita tertinggi yang pernah dicari orang". 25

Dengan demikian, dapat dilihat dengan jelas melalui ungkapan ini Yesus sedang mengklaim keilahian-Nya - secara tidak langsung hendak menegaskan tentang praeksistensinya. Selain Yesus menegaskan bahwa Dia sudah ada jauh sebelum Abraham ada (menjadi), Dia juga menegaskan praeksistensi dan keilahian-Nya.

\section{PENUTUP}

Setelah memberikan penjelasan panjang-lebar tentang topik Pra-eksistensi Yesus yang didasarkan pada bukti-bukti dari Injil Yohanes, maka berikut ini akan dikemukakan beberapa kesimpulan yakni:

1. Dari beberapa bukti dari Injil Yohanes, maka semuanya menegaskan tentang praeksistensi Yesus. Dia sudah ada bahkan jauh sebelum dunia diciptakan Dunia diciptakan oleh Dia.

${ }^{24}$ Kata ini muncul pertama kalinya dalam Kitab Septuaginta untuk menerjemahkan pernyataan YHWH yang menyingkapkan nama-Nya pada Musa sbb: "Firman Tuhan kepada Musa: "AKU ADALAH AKU." Lagi firman-Nya: "Beginilah kaukatakan kepada orang Israel itu: AKULAH AKU telah mengutus aku kepadamu." Frasa "Aku adalah Aku" dalam bahasa Ibrani adalah Ehyeh asyer Ehyeh yang secara literal diterjemahkan dengan "Aku ada yang Aku ada". Dalam naskah Septuaginta (terjemahan TaNaKh dalam bahasa Yunani) diterjemahkan, Ego eimi ho on. (Sumber: http://bet-midrash.blogspot.com/2017/02/makna-pernyataan-ego-eimi-olehyesus.html//03/03/2019//)

${ }^{25}$ Donald Guthrie, Teologi Perjanjian Baru 1 (Allah, Manusia, Kristus), (Jakarta: BPK Gunung Mulia, 1993), 375.
2. Yesus adalah (Anak) Allah atau pribadi kedua dari Allah Tritunggal.

3. Semua ajaran yang menolak ajaran praeksistensi Yesus terbantahkan dan gugur apabila didasarkan pada bukti-bukti dari Injil Yohanes.

\section{KEPUSTAKAAN}

Bauer's, Walter, A Greek-English Lexicon of The New Testament And Other Early Christian Literature (BDAG) Third Edition, Chicago: The University of Chicago Press, 2000, Diedit oleh: Frederick William Danker.

Carson, D.A., The Gospel According to John (The Pillar NTC), Leicester/Grand Rapids: Eerdmans, 1991.

Chamblin, J. Knox, Paulus dan Diri: Ajaran Rasuli bagi Keutuhan Pribadi, Surabaya: Momentum, 2011.

Erickson, Millard J., Teologi Kristen Volume Dua, Malang: Gandum Mas, 2015.

Guthrie, Donald, Teologi Perjanjian Baru 1 (Allah, Manusia, Kristus), Jakarta: BPK Gunung Mulia, 1993.

Kittel-Bromiley, Theological Dictionary of the New Testament (TDNT).

Kostenberger, Andreas J., A Theology John's Gospel and Letters: The Word, the Christ, the Son of God, Grand Rapids, Michigan: Wm. B. Eerdmans Publishing Co., 2009.

Macleod, Donald, The Person of Christ: Contours of Christian Theology, USA: InterVarsity Press, 1998.

Michaels, J. Ramsey, The Gospel of John (NICNT), Grand Rapids: Zondervan, 2010.

Morris, Leon, The International Commentary On The New Testament: The Gospel According To John, Grand Rapids, Michigan: Wm. B. Eerdmans Publishing Co, 1971.

Ryrie, Charles C., Teologi Dasar Jilid 1. Yogyakarta: Penerbit ANDI, 1991.

Ryrie, Charles C., Teologi Dasar Jilid 2. Yogyakarta: Penerbit ANDI, 1991. 
Wallace, Daniel B., Greek Grammar Beyond and Basics. An Exegetical Syntax of The New Testament, Grand Rapids: Zondervan, 1996.

Internet:

http://www.buletinpillar.org/artikel/paul-swriting-on-preexistence-of-christ// https://teologiareformed.blogspot.com/2018/0 9/pra-eksistensi-dan-kekekalankristus.html//

https://saksi-saksiyehuwa.blogspot.com/2014/05/siapakah -yesus-menurut-ajaran-saksiyehuwa.html//

http://bet-midrash.blogspot.com/2017-

/02/makna-pernyataan-ego-eimi-olehyesus.html// 